\title{
Spatial distribution and characteristics of Anopheles larvae breeding places and their relation to larval density in Bulukumba
}

\author{
Iwan Suryadi ${ }^{1}$, Hasanuddin Ishak $^{2}$, \\ \{iwansuryadi@staff.uns.ac.id ${ }^{1}$, hasanuddin.ishaq@gmail.com ${ }^{2}$ \} \\ Department Hygiene and Occupational Health and Safety, Sebelas Maret University UNS, Ir Sutami \\ Road No. 36 A, Solo, Central of Java, Indonesia ${ }^{1}$ \\ Department Environmental Health, Faculty of Public Health, Hasanuddin University, Perintis \\ Kemerdekaan South Of Sulawesi, Indonesia ${ }^{2}$
}

\begin{abstract}
The World Health Organization estimates that 207 million cases of malaria occurred globally in 2012 had resulted in 627 thousand deaths. Bulukumba District is one of the malaria-endemic areas as case reporting every year. The study aims to determine the spatial distribution and analyse habitat characteristics and a density of Anopheles larvae in Bulukumba Regency. The method of the research was observational studies by ecological survey design. The 103 of breeding places situated in 5 subdistricts of Bulukumba were observed namely physical, biological, and chemical characteristics. Distribution of species was expressed on spatial mapping of GIS. The spatial distribution of Anopheles larvae was at a distance of $0-1000 \mathrm{~m}$ from homes of patients that spread in 5 seconds. Physical environmental factors had significant effect on larval density $(\mathrm{p}=0.045)$, alongside with water temperature $(\mathrm{p}=0.017)$, biological environmental factors as the presence of aquatic plants $(\mathrm{p}=0.010)$ and larval predators $(\mathrm{p}=0,000)$, and a chemical environmental factor that was $\mathrm{pH}(\mathrm{p}=0.031)$. Multivariate analysis using linear regression test showed that larval predators were the most influential variable on larval density $(\mathrm{p}=0,000)$. In conclusion, physical, biological and chemical characteristics affect the density of Anopheles sp larvae. The environmental management is needed, especially the breeding habitat of Anopheles sp larvae by sowing predatory fish seeds in permanent habitat types.
\end{abstract}

Keyword: Anopheles larvae, larval

\section{Introduction}

Malaria is still a global public health problem. Nearly half of the world's population is at risk for malaria and causes one million deaths $[1,2]$. Malaria in pregnant women increases the risk of low birth weight babies, infant mortality, abortion, anemia, and even death in pregnant women [3].

The Bulukumba Health Office records the number of malaria cases based on API values from 2009-2014. API in 2009 amounted to 4.29, in 2010 there was an increase in API value to 5.3 , in 2011 the API value decreased to $0.29,2012$ and 2013 API values decreased by 0.13 and 2014 by $0.06 \%$. The decline in the value of API is due to the existence of a global fund program in controlling malaria [4].

Asniar in 2012 concerning confirmation of entomology of malaria cases in Bulukumba Regency there were 6 species of Anopheles mosquitoes that have the potential as transmission vectors namely: An. barbirostris, An. Vagus, An. subpictus, An. Indefinite, An. hircanus and An. Kochi. From the type of mosquito An. barbirostris and An. subpictus is a malaria vector in Bulukumba District [5]. 
The presence of larval habitat is a ubiquitous factor for the occurrence and maintenance of vector population densities, which are directly involved in the rate of malaria spread. The main Neotropic vector is the An. barbirostris and An. subpictus mosquitoes.

Environmental factors have a very important role in the role of health as Anopheles habitat research conducted by Suwito et al. on the relationship of climate, the density of Anopheles mosquitoes and the incidence of malaria showed that mosquito density was associated with an increased incidence of malaria $(P=0.021)[6]$.

Environmental health research will get interesting if using geospatial technology. The fundamental concept of environmental health is related to the place of the life of humans themselves, which are elements of the environment, such as climate, soil, air, and insects [7].

Spatial analysis and distribution are one of the area-based disease management methodologies. Analysis of malaria, for example, considers the number of patients in an area at a certain time by taking into account the variables of rainfall, humidity, vector density, altitude, the location of mosquito breeding sites, and various other variables in an ecosystem [8].

The use of the GIS application and the spatial analysis method makes it easy to control the mapping of malaria vector measures to meet the specific needs of the field team as well as supervisors and program managers in assisting malaria control programs and understanding the spatial distribution of disease [9], [10].

The purpose of this study was to determine the spatial distribution and habitat characteristics with the density of Anopheles larvae in Bulukumba Regency.

\section{Method}

The research design was observational with the design of ecological studies through a cross-sectional approach which aimed to determine the relationship between several variables of the study with environmental samples in the form of larval habitats.

The research was carried out in Bulukumba District. The population of all habitat of Anopheles mosquito breeding. While the research sample is the breeding habitat of the Anopheles mosquito, the sampling method is carried out by purposive sampling. Namely all samples found when conducting research that can be reached and can be carried out. The study sample was at a distance of 100-1000 meters from the case house.

The instruments used in this study were observation sheets, survey equipment, and field laboratory equipment in the form of injuries, pipettes, larval containers, net larvae, gutters, digital salt meters, GPS, $\mathrm{pH}$ meters, label paper, and writing instruments.

Determination of larvae and density is done by scooping up a body of water, where for a narrow water body is done 10 times while for a broad water body is done more than 10 times. If the results of the wound contain larvae, the species is observed for the larvae; if the larval position is parallel to the surface of the water, then the larvae are Anopheles.

Analysis of data from observations and entomology surveys was carried out with the univariate analysis in the form of tables and graphs with narration as an explanation, bivariate analysis to determine the effect and correlation between variables, and multivariate analysis to determine the strength of influence among variables.

Identification of Anopheles larvae species by collecting them in a sample bottle and rearing them to become adult mosquitoes, then preserved in Effendorf tube containing silica 
gel and cotton. Calculation of larval density is done by formula. Other paragraphs are indented (BodytextIndented style).

$$
\text { density }=\frac{\text { number of caught }}{\text { captured number of larvae }}
$$

\section{Results}

The type of research used in this study is observational with the design of ecological studies. Through the environmental approach, this study looked at the breeding place characteristics with the larval density data of local malaria sufferers. Sampling is set at a 5001000 meter radius from the patient's home.

\subsection{Spatial distribution of Anopheles larvae}

The study area is a foot mountainous area, namely Rilau Ale, and Bulukumpa District and part of the hill and coastal areas are Bontotiro District, Bontobahari District, Ujungbulu District, and Ujung Loe District. Geographical conditions from 6 sub-districts are different. This research was conducted by observing the habitat of larvae of Anopheles sp. within a radius of 500-1000 meters from a malaria case. Furthermore, the positive and negative habitat of Anopheles sp. Larvae were determined. And the larval density of each positive habitat for Anopheles sp. larvae.

Environmental characteristics were also measured to analyze the effect on larval density. Figure 1 shows as many as 103 habitats observed, in various research districts. Distribution of cases and various types of habitat types within a radius of 500-1000 meters. The case buffer aims to describe a positive or negative habitat type that is within a radius of 500-1000 meters. Figure 1 shows a small portion of positive habitats located around the case house with high rice field habitat types found positive for Anopheles sp. Larvae.

The species of larvae that have been identified in this sub-district are quite varied, namely An vagus mostly in the type of rice field habitat, the rest is found in puddles and footprints, An. Hyrcanus is found in the rice field type habitat, An. subpictus is found in paddy and pond type habitats, An. Indefinite is found in rice field type habitats and An. barbirostis is found in river type habitats, swamps and rice fields. Distribution of Anopheles species can be seen in Figure 1.

Distribution of Anopheles sp. Larvae. Varies between different sub-districts in Bulukumba. For larvae An. barbirostris can be found in highland and lowland areas. Larva An. barbirostris is found in Bulukumpa district, Rilau Ale, Ujungbulu and Ujung Loe with habitat types in the form of rice fields, rivers, pools, and swamps. As for the larval distribution of An. subpictus, where the larva An. subpictus is dominant in Bontobahari, Ujung Loe and Ujungbulu. This indicates that An. subpictus is found in coastal areas with pond habitat types. Distribution of larval species An. Hyrcanus and An. Indefinite is spread in Bulukumpa and Rilau Ale districts with the dominant habitat in rice fields, while for larvae An. Vagus is spread throughout the study area.

The public health center which is the location of research is the Public Health Center (PHC) Cable in Ujungbulu District, PHC Ujung Loe in Ujung Loe District, PHC Bontotiro and PHC 
Batang in Bontotiro District, Bontobangun PHC in Rilau Ale and PHC Tanete Districts in Bulukumpa.

Table 1 shows the distribution of Anopheles larvae based on the PHC region, where larvae An. barbirostris is distributed in PHC Caile, Bontobangun, Tanete, and Ujung Loe, larvae An. subpictus is distributed in PHC, Bontobahari, Bontotiro and Ujung Loe. Larvae An. Vagus is spread in PHC Caile, Bontobahari, Batang, Tanete, Bontobangun, and Ujung Loe. Larvae An. Hyrcanus and larva An. indefinite is spread in PHC Tanete and Bontobangun.

Table 2 shows the distribution of breeding place for Anopheles larvae, were the larvae of An.barbirostris, An. Vagus, An. Hyrcanus and An. Indefinite dominant was found in rice fields while larvae An. subpictus is dominantly found in ponds and ponds. Table 3 shows the breeding place characteristics of each type of Anopheles larvae, which consists of physical environmental characteristics, biological environment, and chemical environment.

Table 4 uses the crucial wails test to see the difference in density between permanent and non-permanent breeding places where there is a significant difference with $\mathrm{p}=0.045$, table 5 shows the significant effect between water temperature and larval density with $p=0.017$ and $r$ $=0.235$ which means the higher the water temperature, the higher the larval density. Table 6 shows the significant difference between aquatic plant and larval density with $p=0.010$. Table 7 shows that there is a significant effect between larval predators and larval density with $\mathrm{p}=$ 0,000 and $r=0.423$, which means that breeding places that do not have larval predators are higher in the density of Anopheles larvae.

Table 8 shows the significant effect between water $\mathrm{pH}$ and larval density with a value of $\mathrm{p}=$ 0.031 and the value of $\mathrm{r}=0.213$ shows that the higher the $\mathrm{pH}$ of the water the higher the density of the Anopheles larvae. Linear regression test as in Table 9 shows that larval predators are the most influential variable on the density of Anopheles larvae with $p=0,000$. The adjusted square value is 0.227 , which means that the larval predator gives an effect of $22.7 \%$ on larval density, and other variables influence $76.3 \%$. Beta coefficient values indicate that larval predators can predict larval density with a correlation of 0.340

\section{Discussion}

This study found 6 cases of case houses, namely 2 point case houses in Bulukumpa District, and 4 points in Bontobahari District. From the home point of the case, the researchers found that they observed potential habitat for the breeding of Anopheles sp. Larvae. In this study, focused habitats were defined as habitats within a radius of 500 meters from malaria cases with consideration of mosquito flying distance, which is very limited in the range of 400 meters. The transmission of transmission develops widely because several variables that influence one of them are population mobility activity [11].

The study found that in Bulukumpa and Bontobahari districts where after spatial analysis with buffer method showed that at a distance of 500 meters from the house of malaria patients there was a positive habitat for breeding of Anopheles sp larvae so that at a distance had a strong influence as the transmission of malaria spread. This is relevant to Rohani et al. (2010) research, showing the relationship between the distance of a malaria patient's house and the breeding habitat of Anopheles sp larvae as seen from the distance of a case house with a positive habitat. This shows a strong relationship between the distance of breeding habitats and transmission of malaria spread [12].

Distribution of various types of Anopheles larvae which become malaria vectors in Bulukumba Regency, namely An. barbirostris and An. subpictus shows that An. barbirostris is predominantly found in Bulukumpa, Tanete and Ujung Loe Districts with habitat types in the 
form of rice fields, rivers, and swamps, while An. subpictus is predominantly found in Bontobahari and Ujung Loe Districts with habitat types in the form of ponds.

An. barbirostris and An. subpictus which is a potential vector on the island of Sulawesi. An. barbirostris is generally found in hilly and rice fields while An. subpictus is found in coastal areas although it does not rule out the possibility that An. barbirostris can be found in coastal areas and An. subpictus likes rice fields.

Habitat characteristics An. barbirostris such as rice fields, rivers, and swamps are found in highland areas in Bulukumpa and Rilau Ale Districts and lowland areas such as Ujungbulu and Ujung Loe Districts.

The different types of mosquito species found are also related to the topography of a region; this can be seen in Figure 1 about the type of species distribution in Kab. Bulukumba that An. barbirostris is found at altitudes ranging from 8-448 mdpl which indicates that An. barbirostris can be found in lowlands and highlands.

This is relevant to other studies, namely An. barbirostris has also been found to be associated with higher altitudes, paddy fields, shallow water depths, higher water temperatures, high $\mathrm{pH}$ and salinity, and an average distance further from human habitation [13],[14].

Research conducted by Ndoen et al. (2010), shows that An. barbirostris in the area of Central Java is more commonly found in areas in the highlands while in the East-West region (NTT) more are found in coastal areas and An. barbirostris can be found at an altitude of 0 $800 \mathrm{~m}$. An. Significant subpictus was found in coastal areas, namely in Bontobahari with habitat characteristics in the form of ponds and Ujung Loe also found in rice fields at altitudes of 8-100 m above sea level. This is relevant to the research conducted by Ndoen that An. subpictus relates to lagoons, brackish water, and mangrove forests that receive direct sunlight [15].

An. subpictus in the area of Central Java was found in hilly rice fields, while in the EastWest region it was found dominantly in coastal areas. This shows that the topography of the region influences the spread of Anopheles sp species.

Topography has a strong influence on the presence of the Anopheles mosquito where the topography shows that An. barbirostris can be at any height while An. subpictus is predominantly found in coastal areas such as research conducted by Ndoen et al. while An. subpictus at an altitude of 0-200 $\mathrm{m} \mathrm{[15].}$

An. Vagus and An. indefinite is found in the highlands and lowlands, namely in the type of habitat in the form of rice fields. An. vagus and An. indefinitus is not found in pond habitats. For An. hyrcanus is found in mountainous regions with the majority of habitat types in the form of rice fields.

\subsection{Physical environmental characteristics}

The characteristics of the physical environment that are the research variables here are water temperature, breeding habitat types, water depth, sunlight intensity, water flow, and habitat properties. The results of the bivariate analysis of physical environment variables that influence the density of Anopheles larvae include habitat type and water temperature.

In nature. barbirostris can inhabit larvae such as small ponds, swamps, and rice fields. Whereas in South Lampung, An breeding place is found. barbirostris is found in An larvae breeding sites. barbirostris in rice fields with moderate sunlight intensity, in Manggala, North Lampung, An larvae were found. barbirostris in the rice field with a water pH between 4.5 7.0. In Sikka Flores larvae. Barbers are found in flowing rivers and lagoons with a salt content of $0.2-10.4 \%$. In general, the habitat favored by An larvae. barbirostris of sunlit water bodies, 
such as lagoons, ponds, slow running waterways, along river banks, and rice fields and vegetation overgrown with vegetation [16].

Research that supports habitat characteristics of An. barbirostris, including research on dominant malaria vectors in the Asia Pacific region, shows that larval habitat is An. barbirostris has a type of brackish water habitat that is low in salinity, swamps, artificial lakes, rice fields, irrigation channels, and ponds with a correlation value $=0.866$ [17].

Water temperature affects larval proliferation. In general, larvae of Anopheles mosquitoes prefer high temperatures when compared to the type of cuisine. That is why more Anopheles species are encountered in the tropics.

The hatching time of Anopheles mosquito eggs is strongly influenced by the temperature of the water at the breeding site. The higher the water temperature, the shorter the time. Water temperature correlates with the larval density of An. barbirostris in Ujung Loe with average larvae An. barbirostris was found at the water temperature that fulfilled the requirements; the results of multivariate analysis and analysis showed that the water temperature had the strongest influence on the larval density of An. barbirostris in Ujung Loe District is compared to variables. This is in line with research conducted by Christiansen et al. (2014), regarding the relationship of temperature to larval propagation shows that the optimal temperature for larval development of An. gambiae between $23-31^{\circ} \mathrm{C}$. Likewise with research by Rohani et al. (2010), about habitat characteristics and mapping of An. maculatus in Malaysia shows water temperature in each of the studied habitats 21-31 0C [18], [12].

\subsection{Biological environmental characteristics}

Research shows a significant relationship between aquatic plant and a density of Anopheles larvae. This is consistent with research by Kevin A and Caillouët (2008). Water plants in the breeding site play a role in the presence of Anopheles larvae. This is because the aquatic plants can function as a place to disinfect mosquitoes when on the surface of the water [19].

Algae and decaying water plants on the surface of the water that spread widely and gets direct sunlight greatly affect the proliferation of larvae, this is caused by microfauna and microflora as food ingredients for many larvae gathered around the plant.

Water plants or vegetation found in the larval breeding habitat of An. subpictus in the form of moss and grass. The existence of vegetation or aquatic plants can increase larval density because water vegetation becomes a hiding place for larvae from predators and protects the habitat from direct sunlight to reduce water temperature. The presence of predators affects the density of Anopheles larvae. Research by Michael El al (2005) with a value of $p=0.040$ after logistic regression analysis, there was a predator influence on the presence of Anopheles larvae. This shows that there are more predators, so the density of larvae decreases. In the research location, the majority of breeding places have no predators [20].

\subsection{Chemical, environmental characteristics}

The degree of acidity $(\mathrm{pH})$ is used in the regulation of respiration and enzyme systems in the body of mosquito larvae. In this study showed a significant relationship between $\mathrm{pH}$ and density of mosquito larvae. This is consistent with the study by Paulo et al. (2016) that the $\mathrm{pH}$ favored by mosquitoes ranged from 6-9 with a p-value of 0.008 at An. darling [21]. 


\section{Conclusion}

Physical environmental characteristics of larval predators are the most influential variables on the density of Anopheles larvae. The distribution of Anopheles larvae found in this study was in the form of An.barbirostris, An.subpictus, An.vagus, An.hyrcanus and An. indefinite. It is suggested that cooperation between the Bulukumba District Health Office and the Public Works Agency be needed to improve the irrigation system, especially for temporal habitats to overcome the breeding habitat of Anopheles sp larvae.

Acknowledgments. We would like to thank Bulukumba health service for the licensing of this research and the Hasanuddin University entomology laboratory for identification of larvae.

\section{References}

[1] Hay C, Guerra A, Tatem A, Noor R, Snow R.: The global distribution and population at risk of malaria: past, present, and future. Lancet Infect Dis. Vol. 4, pp. 327-336 (2005)

[2] Hay SI, Guerra CA, Gething PW, Patil AP, Tatem AJ, Noor AM, Kabaria CW, Manh BH, Elyazar IR, Brooker S.: A world malaria map: Plasmodium falciparum endemicity in 2007. Vol.6.pp.6-7. (2007)

[3] Ward SA, Sevene EJ, Hastings IM, Nosten F, McGready R.: Antimalarial drugs and pregnancy: safety, pharmacokinetics, and pharmacovigilance. Lancet Infect Dis. Vol. 7, pp 136-14. (2007)

[4] Dinas Kesehatan Kabupaten Bulukumba.: Laporan Malaria. Bulukumba. (2013)

[5] Asniar, A, Ishaq, H, \& Wahid, I.: Konfirmasi Entomologi Kasus Malaria Pada Sepuluh Wilayah Puskesmas Di Kabupaten Bulukumba. repisitori Unhas. pp.1-9. (2012)

[6] Suwito, Upik Kusuma Hadi, Singgih H Sigit, dan Supratman Sukowati.: Hubungan Iklim, Kepadatan Nyamuk Anopheles dan Kejadian Penyakit Malaria. J. Entomol. Indon. pp 4253. (2010)

[7] Maantay, J. A.: Geospatial Analysis of Environmental Health. In S. mclaverty (Ed.), geotechnology and the environment. Springer : USA. Vol.3.pp.11-19. (2011)

[8] Achmadi, U. f 2008 Manajemen Penyakit Berbasis Wilayah. UIP : Jakarta.

[9] Dongus, Stephen, Victoria Mwakalinga, Khadija Kannady, Marcel Tanner, and Gerry Killeen.: Participatory Mapping as a Component of Operational Malaria Vector Control in Tanzania. Springer. Vol. 4, pp. 321-322. (2011)

[10] Hanafi Bojda, A. A., H Vatandoosta, M. A Oshaghia, Z Charrahyb, A. A Haghdoostc, G Zamanid, F. Abedi, M.M Sedhagat, M. Soltani, M. Shahi, A. Raesi.: Spatial Analysis and Mapping of Malaria Risk in An Endemic Erea, South of Iran. A GIS Based Decision Making for Planning of Control. Acta tropica elsevier Journal. Vol.7. pp. 132-137. (2012)

[11] Santjaka.: Malaria Pendekatan Model Kausalitas. Nuha Medika (2013)

[12] Rohani, A., WMA Najdah, I Zamree. AH Azahari, I Mohd Noor, H. Rahimi, HL Lee.: Habitat Characterization And Mapping Of Anopheles Maculatus (Theobald) Mosquito Larvae In Malaria Endemic Areas In Kuala Lipis, Pahang, Malaysia. Vol.1. pp. 1-10. (2010)

[13] Stoops, C. A., Yoyo R Gionar, Shinta, Priyanto Sismadi, Iqbal RF Elyazar, Michael J Bangs and Supratman Suowati.: Environmental factors associated with spatial and temporal distribution of Anopheles. larvae in Sukabumi, West Java, Indonesia. Journal of Medical Entomology. Vol. 1, pp.1-9. (2008)

[14] Stoops, C. A., Yoyo R Gionar, Shinta, Priyanto Sismadi, Iqbal RF Elyazar, Michael J Bangs and Supratman Suowati.: Remotely-sensed land use patterns and the presence of Anopheles larvae in Sukabumi, West Java, Indonesia. Journal Of Vector Ecology. Vol.5. pp. 36-38. (2008)

[15] Ndoen, E., Clyde Wild, Pat Dale, Neil Sipe, and Mike Dale.: Relationships between anopheline 
mosquitoes and topography in West Timor and Java, Indonesia. malaria journal. Vol.2. pp. 49. (2010)

[16] Elyazar, Iqbal. R. F., Marianne E Snka., Peter W Gething., Siti N Tarmidzi., Asik Surya Kusriastuti, Winarno. J. Kevin Baird., Simon I Hay., Michael J Bangs.: The Distribution and Bionomics of Anopheles Malaria Vector Mosquitoes in Indonesia. Elsevier. Vol.9. pp. 186189. (2013)

[17] Sinka, Marianne E., Michael J Bangs., Sylvie Manguin., Therephap Chareonviriyaphap., Anand P Patil., William H Temperley., Peter W Geting., Iqbal RF Elyazar., Caroline W Kabaria., Ralph E Harbch and Simon I Hay.: The Dominant Anopheles Vectors Of Human Malaria In The Asia-Pacific Region: Occurrence Data, Distribution Maps And Bionomic Précis. Parasites \& Vectors. Vol.2 pp. 1-78. (2011)

[18] Christiansen-Jucht, Celine., , Paul E. Parham ., Adam Saddler., Jacob C Koella., and Maria Gloia Basáñez.: The temperature during larval development and adult maintenance influences the survival of Anopheles gambiae s.s. Parasites \& Vectors. Vol.7. pp. 1-10. (2014)

[19] Kevin A. Caillouët, J. K., and Thomas P. Eisele.: Characterization of aquatic mosquito habitat, natural enemies, and immature mosquitoes in the Artibonite Valley, Haiti. Journal Of Vector Ecology. Vol.7. pp. 191-198. (2008)

[20] Sattler, Michael A., Deo Mtasiwa., Michael Kiama., Zul Premji., Marcel Tanner1., Gerry F Killeen1., and Christian Lengeler.: Habitat characterization and spatial distribution of Anopheles sp. mosquito larvae in Dar es Salaam (Tanzania) during an extended dry period. Malaria Journal. Vol.4. pp. 1-15. (2005)

[21] Moutinho, Paulo Rufalco., Nicolás Schweigmann., Denise Pimentel Bergamaschi., Maria Anice Mureb Sallum.: Larval habitats of Anopheles species in a rural settlement on the malaria frontier of southwest Amazon, Brazil. Acta tropica Elsevier. Vol. 164.pp. 243-258. (2016) 